\title{
RANCANG BANGUN SMART SLIDING WINDOW SEBAGAI PEMANDU WISATA MUSEUM MENGGUNAKAN METODA RAPID PROTOTYPING STUDI KASUS MUSEUM GEOLOGI BANDUNG
}

\author{
Muhammad Andik Izzuddin $^{1}$, Ary Setijadi Prihatmanto ${ }^{2}$, Eko Nugroho $^{3}$
}

School of Electrical Engineering and Informatics

Bandung Institute of Technology, Ganesa Street 10, Bandung 40132, Indonesia

$\underline{1 \text { andik32@ gmail.com, }}, \underline{2 \text { asetijadi@1skk.ee.itb.ac.id, }}{ }^{3}$ enugroho@gmail.com

\begin{abstract}
Dengan ditemukannya mikroprosesor pada tahun 1980an, bidang keilmuan mekatronika menjadi lebih maju dan berkembang. Kemudian para produsen mikroprosesor telah berinovasi dengan menciptakan jenis lain dari prosesor yang disebut mikrokontroler. Mikrokontroler pada dasarnya merupakan pengembangan dari jenis mikroprosesor tradisional dengan peningkatan kemampuan khusus terutama untuk aplikasi kontrol.

Permuseuman di Indonesia dewasa ini secara fisik cukup meng-gembirakan, namun hal tersebut kurang diimbangi per-kembangan pengetahuan dan kemampuan teknis dalam menyampaikan informasi permuseuman. Dalam hal ini ditangani oleh Pamong Budaya atau disebut juga Pemandu Museum. Pemandu Museum adalah orang terdepan dalam memberikan bimbingan, penerangan dan petunjuk mengenai koleksi museum serta pelayanan lainnya. Dalam memberikan pelayanan kepada wisatawan dituntut mampu dan memahami sesuai dengan bidang tugasnya.

Melihat potensi bidang mekatronika untuk diterapkan dalam Museum sebagai pemandu dengan studi kasus di Museum Geologi Bandung pada bagian display artefak kerangka dino-saurus. Oleh karena itupenelitian ini bertujan membuat rancang bangun Smart Sliding Window menggunakan metoda rapid prototyping. Hasil pengujian aspek kepuasan antarmuka pengguna dan usabilitas menggunakan dasar evaluasi Chip, JP, Diehl, VA. Norman, KL (1988) dan Lewis, JR (1995), menun-jukkan bahwa Smart Sliding Window dapat memberikan kepuasan antarmuka dengan fungsi yang cocok bagi pengguna dan memberikan kontrol serta kebebasan bagi pengguna.Pengujian aspek usability menunjukkan bahwa pengguna dapat memperoleh manfaat dari keberadaan sistem, dan mudah untuk digunakan.
\end{abstract}

Keyword: digital museum, antarmuka pengguna, usability, mikrokontroller, rapid prototyping.

\section{PENDAHULUAN}

Mekatronika adalah proses desain yang mencakup kombinasi dari teknik mesin, teknik elektro, teknik kontrol dan teknik komputer [1]. Istilah ini dicetuskan pertama kali oleh Tetsuro Mori dari Yasakawa Electric Company pada tahun 1969. Tetapi sejak tahun 1982 perusahaan tersebut memutuskan untuk melepaskan haknya atas kata mekatronik sehingga sejak saat itu pula kata tersebut dipakai secara luas. Dengan ditemukannya mikroprosesor pada tahun 1980an, keilmuan mekatronika menjadi lebih maju dan berkembang. Kemudian produsen mikroprosesor telah menciptakan jenis lain dari prosesor yang disebut mikrokontroler. Mikrokontroler pada dasarnya merupakan pengembangan dari mikroprosesor tradisional dengan peningkatan kemampuan khusus terutama untuk aplikasi kontrol.

Perkembangan Permuseuman di Indonesia dewasa ini secara fisik cukup menggembirakan,namun hal tersebut kurang diimbangi perkembangan pengetahuan dan kemampuan teknis dalam menyampaikan informasi permuseuman. Dalam hal ini ditangani oleh Pamong Budaya atau disebut juga Pemandu Museum. Pemandu Museum adalah orang terdepan dalam memberikan bimbingan, penerangan dan petunjuk mengenai koleksi museum serta pelayanan lainnya. Dalam memberikan pelayanan kepada wisatawan dituntut mampu dan memahami sesuai dengan bidang tugasnya [2].

Preece, Rogers dan Sharp (2002) mendefinisikan desain interaksi sebagai desain produk interaktif yang membantu orang dalam kehidupan sehari-hari dan bekerja mereka. Mereka berpendapat bahwa desain interaksi adalah untuk menciptakan pengalaman pengguna yang meningkatkan cara orang bekerja, berkomunikasi dan berinteraksi, atau lebih banyak dipahami sebagai konsep di balik kebergunaan. Ini berkaitan dengan pemahaman bahwa sebuah antarmuka, baik berupa layar ATM atau aplikasi ponsel, seharusnya mudah dan menyenangkan digunakan. Proses interaksi ini melibatkan pengguna dengan komputer pada antarmuka pengguna, termasuk di dalamnya adalah perancangan hardware dan software [3].

Berdasarkan hal tersebut, penelitian akan dilakukan dengan mengambil contoh kasus di Museum Geologi Bandung pada bagian display artefak kerangka dinosaurus dengan penggunaan rancang bangun smart sliding windowsebagai pemandu wisata museum menggunakan metoda rapid prototyping. Hasil yang diharapkan dari penelitian ini adalah desain dan implementasi berbasis teknologi informasi melalui Smart Sliding Window sehingga diharapkan memberikan 
manfaat kepada pengunjung yang menggunakan alat tersebut dan lebih jauh lagi mampu meningkatkan antusias masyarakat untuk mengunjungi museum.

\section{RANCANG BANGUN}

Sebuah prototipe adalah sampel awal atau model yang dibangun untuk menguji suatu konsep atau proses atau bertindak sebagai hal yang harus direplikasi atau dipelajari. Istilah ini digunakan dalam berbagai konteks, termasuk semantik, desain, elektronik, dan program perangkat lunak. Sebuah prototipe dirancang untuk menguji dan untuk percobaan desain baru dalam rangka meningkatkan presisi bagi analis sistem dan pengguna. Prototyping berfungsi untuk memberikan spesifikasi sistem kerja nyata dari suatu konsep yang teoritis [4].

Dengan memanfaatkan peningkatan
kemampuan dari aplikasi perangkat lunak, para
perancang telah memulai menggunakan metode
pendekatan desain baru yang dikenal dengan rapid
prototyping. Berdasarkan Lantz (1986) "rapid software
prototyping adalah metodologi dalam pembangunan
sistem berdasar pada pembangunan dan menggunakan
model sistem untuk merancang, melaksanakan,
melakukan pengujian dan instalasi sistem"[5]. Dalam
metodologi ini, setelah pernyataan singkat tentang
kebutuhan dan tujuan, penelitian dan pengembangan
yang dilakukan sebagai proses paralel yang menciptakan
prototipe, yang kemudian diuji kemungkinan
untukberkembang menjadi produk akhir.

Microsoft Kinect adalah perangkat yang menggunakan gerakan penggunanya sebagai kontroler. Microsoft Kinect dibangun dari teknologi perangkat lunak yang dibangun oleh Rare, anak perusahaan dari Microsoft Game Studios, sedangkan sensor kamera pada Microsoft Kinect dikembangkan oleh pengembang Israel, PrimeSense yang dapat menafsirkan gesture tertentu kedalam serangkaian kontrol. Teknologi kamera yang digunakan terdiri dari sebuah pemancar dan penerima infra merah, sebuah kamera RGB dan microchip khusus untuk mendeteksi gerakan obyek dan manusia dalam skala tiga dimensi.

Mikrokontroler adalah sebuah sistem komputer lengkap dalam satu chip. Mikrokontroler lebih dari sekedar sebuah mikroprosesor karena sudah terdapat atau berisikan ROM (Read-Only Memory), RAM (ReadWrite Memory), beberapa bandar masukan maupun keluaran, dan beberapa peripheral seperti pencacah/pewaktu, ADC (Analog to Digital converter), DAC (Digital to Analog converter) dan serial komunikasi [6].

Penelitian ini bertujuan untuk merancang dan menentukan disain interaksi smart sliding window sebagai pemandu wisata museum dan untuk mengimplementasikan rancang bangun smart sliding window dengan uji kuantitaif kepuasan user interface dan usability kepada pengguna sehingga diharapkan mampu menarik minat masyarakat terhadap Museum Geologi Bandung.

Batasan masalah dari penelitian ini memiliki batasan pada hasil sebagai berikut.

1. Pembahasan difokuskan pada desain dan rancang bangun berdasarkan kajian desain interaksi pengguna dengan alat smart sliding window.

2. Desain difokuskan pada antarmuka antara pengguna dengan alat smart sliding window yang berjalan pada sistem yang stand alone, Personal Computer (PC).

3. Antarmuka yang dibahas dalam penelitian ini difokuskan pada antarmuka mekanisme penjejak pengguna melalui Kinect dan konten video dengan batasan satu orang pengguna.

4. Lingkungan uji kuantitaif kepuasan user interface dan usability penggunaan alat smart sliding window ini adalah dalam lingkungan Museum Geologi Bandung.

5. Pengujian rancang bangun smart sliding window sebagai pemandu wisata museum dilakukan pada masyarakat yang datang ke Museum Geologi Bandung.

\section{ANALISIS DAN DESAIN SISTEM}

Perancangan desain smart sliding window yang mampu mengikuti pergerakan pengguna secara umum ditampilkan pada gambar berikut ini.

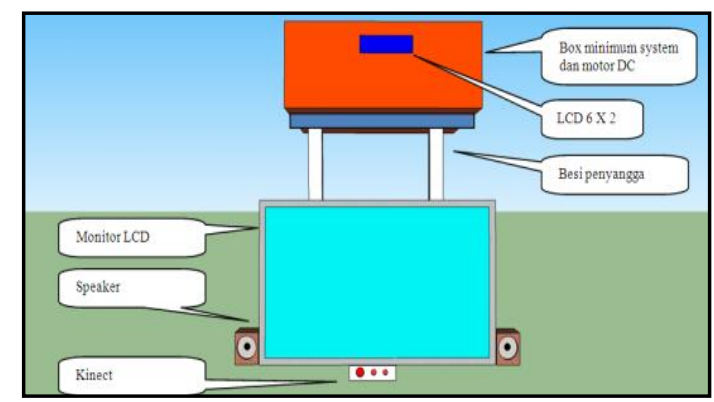

Gambar 1 Rancangan Smart Sliding Window.

Sedangkan bentuk prototipe keseluruhan dengan jalur smart window pada gambar berikut ini.

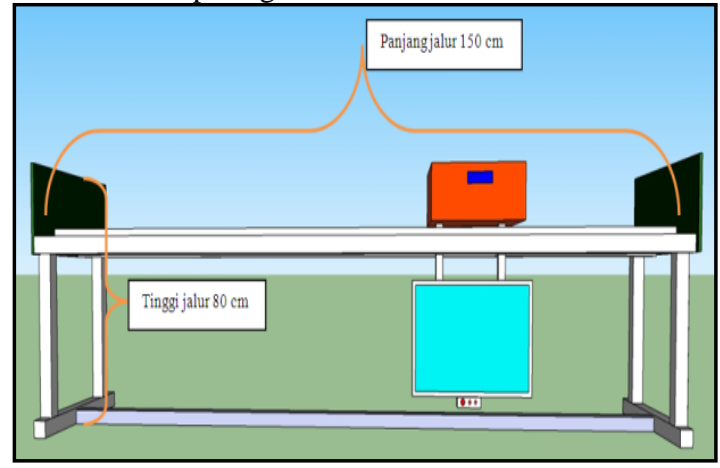

Gambar 2 Rancangan Keseluruhan Smart Sliding Window.

Untuk mempermudah perancangan, maka dilakukan analisa kebutuhan sistem secara lengkap 
seperti yang dijelaskan berdasarkan kebutuhan fungsional dan non fungsional di bawah ini.

\section{A. Kebutuhan Fungsional}

Kebutuhan fungsional berisi tentang pendefinisian layanan yang harus disediakan dan bagaimana reaksi sistem terhadap input. Pada aplikasi ini diharapkan sistem memiliki fungsi antarmuka yang dapat mendukung pengguna dapat melakukan hal-hal di bawah ini:

1. mengikuti pergerakan pengguna sepanjang jalur yang ditentukan,

2. mendeteksi keberadaan pengguna yang berada di depan sistem sliding window,

3. memilih menu informasi dalam monitor sesuai yang disediakan,

4. Kembali pada posisi awal ketika pengguna selesai menggunakan alat.

\section{B. Kebutuhan Non Fungsional}

Kebutuhan non fungsional menjabarkan apa-apa saja yang harus dimiliki oleh sistem agar dapat berjalan. Analisa kebutuhan non fungsional bertujuan untuk mengetahui sistem seperti apa yang cocok diterapkan, perangkat lunak dan perangkat keras apa saja yang dibutuhkan serta siapa saja pengguna yang akan menggunakan sistem ini.

Sistem yang akan dikembangkan merupakan sistem untuk penjejak pengguna dalam lingkungan Museum Geologi Bandung, dimana sampai dengan sekarang, Museum Geologi Bandung menjadi pusat tujuan wisata edukatif bagi masyarakat di Kota Bandung dan sekitarnya yang menyediakan informasi berupa bendabenda sejarah dan artefak masa lampau yang koleksinya bersifat passif dan mempunyai peluang untuk disajikan lebih baik dengan menggunakan bantuan teknologi sehingga dampak yang diharapkan, pengunjung dapat ter-edukasi dengan lebih baik dari sebuah benda koleksi yang bersifat pasif dan sedikit sekali informasi penunjang untuk mengetahui lebih lanjut terhadap benda yang di pamerkan.

Dalam pengembangan Smart Sliding Window, maka harus ditentukan siapa pengguna dan apakah yang dibutuhkan oleh pengguna. Tujuan aplikasi disesuaikan berdasarkan referensi tren teknologi edukatif atau tren yang ada di masyarakat. Materi konservasi dalam pendidikan formal diturunkan melalui setiap jenjang pendidikan secara integratif dengan materi-materi yang lain. Smart Sliding Window dikembang-kan sebagai media berbasis teknologi yang menggambarkan konsep edukatif dan bersifat aktif dengan menambahkan pengalaman yang lebih dari sebuah kunjungan terhadap benda museum yang dominan bersifat pasif menjadi lingkungan yang interaktif melalui sajian virtual yang muncul di monitor.

Kuisioner digunakan untuk mengukur interface satisfaction dan usability dari hasil implementasi alat smart sliding window terhadap pengguna. Pertanyaanpertanyaan di dalam lembar kuisioner dibuat dalam skala Likert's Summated Rating (LSR) dengan memberikan tanda centang $(\sqrt{ })$ pada lima (5) pilihan jawaban. Kriteria penilaiannya dengan skoring, dimana skor 5 untuk sangat setuju, skor 4 untuk setuju, skor 3 untuk kurang setuju, skor 2 untuk tidak setuju, dan skor 1 untuk tidak berpendapat.

Dengan menggunakan mikrokontroller jenis AVR ATMega16 dan dengan menggunakan bahasa $C$ melalui aplikasi pemrograman CodeVision AVR, aplikasi dirancang agar system mampu menerima data dari komputer dan meneruskannya ke motor DC dengan memperhatikan data jarak kiri dan kanan melalui sensor SRF-04. Maka dibuatlah diagram alir sebagai berikut:
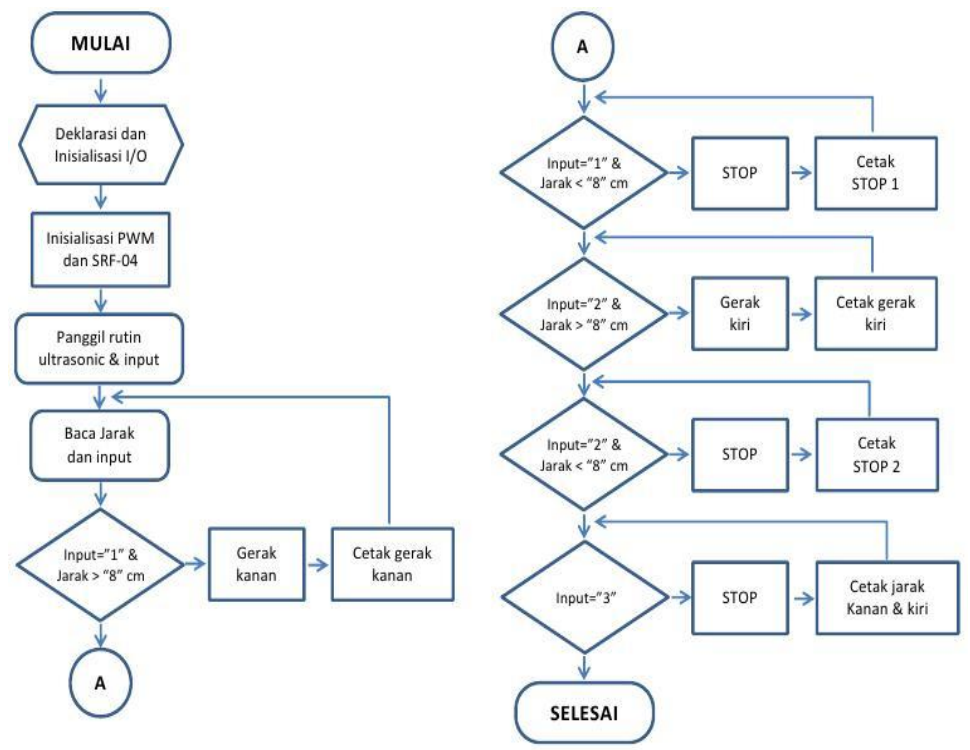

Gambar 3 Diagram Alir Smart Sliding Window 


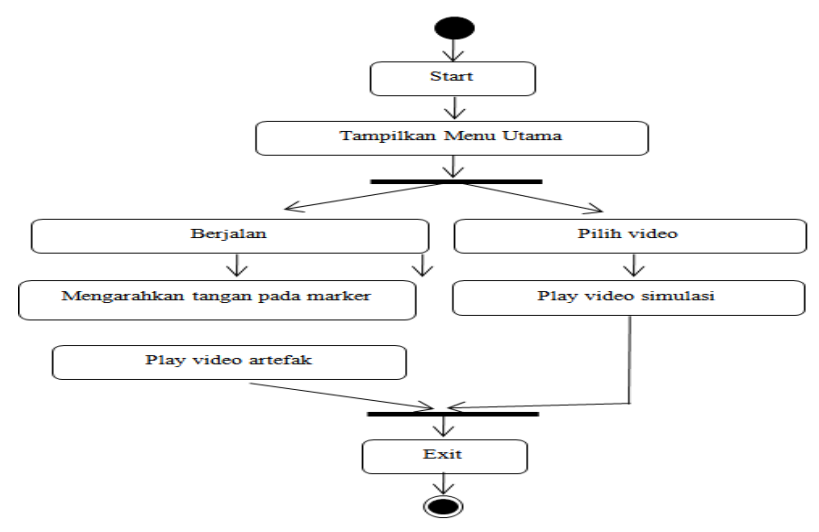

Gambar 4 Diagram aktivitas Smart Sliding Window.

Diagram aktivitas adalah perilaku alur kerja utama suatu sistem. Diagram aktivtas mirip dengan diagram state karena aktivitas merupakan suatu kondisi (state) yang sedang melakukan sesuatu. Diagram menggambarkan aktivitas kondisi dengan menunjukkan kondisi yang bersyarat atau parallel. Berikut adalah diagram aktivitas dari alat smart sliding window.

\section{IMPLEMENTASI DAN PENGUJIAN}

Tujuan dari tahap implementasi adalah untuk memastikan perangkat keras dan perangkat lunak yang dibuat dapat bekerja secara efektif sesuai dengan yang diharapkan. Setelah tahap perancangan selesai, maka tahap selanjutnya adalah implementasi program yang telah dirancang pada perangkat keras Smart Sliding Window.

\section{A. Implementasi Mekanik Smart Sliding Window \\ Implementasi prototipesmart sliding} windowdirancang menggantung dengan posisi jalur yang berada di atas sehingga tidak menggangu pergerakan pengunjung museum yang lain, diharapkan juga dengan sistem seperti ini maka produk akan terkesan rapi karena tidak ada kabel dan perangkat lain yang terlihat di lantai, hanya monitor dan alat penunjang lain seperti Kinect dan speaker yang tampak oleh pengunjung yang menggunakan sistem. Tampilan yang diberikan pada saat pengguna menggunakan alat ini adalah sebagai berikut.

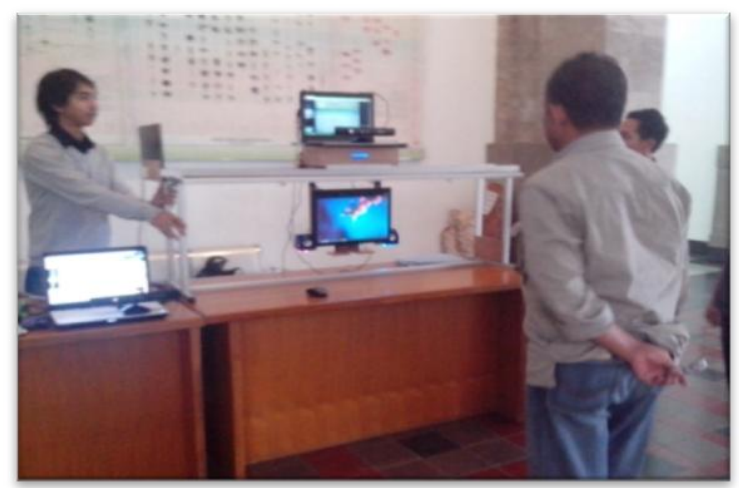

Gambar 5 PrototipeSmart Sliding Window

\section{B. Implementasi Navigasi Smart Sliding Window}

Smart sliding window menggunakan Kinect sebagai sensor pergerakan dari pengunjung. Keberadaan pengunjung yang bergeser baik ke kanan atau kekiri akan diteruskan oleh komputer ke Mikrokontroller ATMega16 dan akhirnya diteruskan pada motor DC yang akan berputar sesuai jalur yang ada.

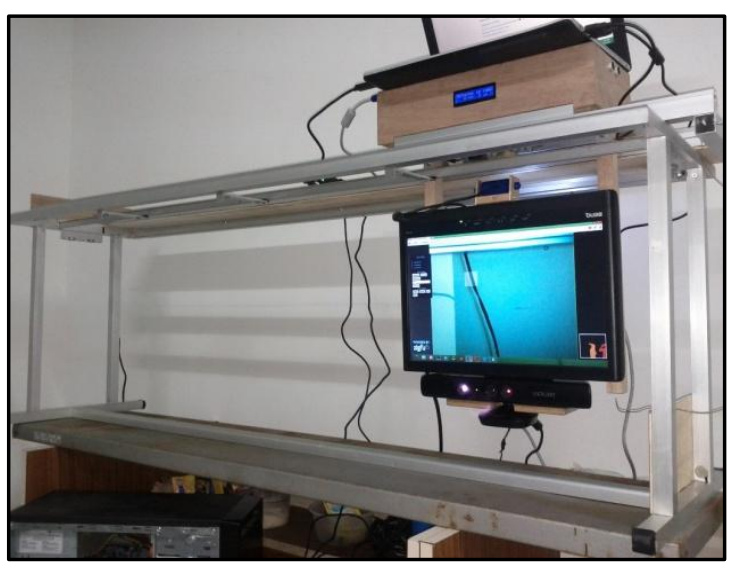

Gambar 6 PrototipeSmart Sliding Window Ketika Sedang Digunakan.

Informasi dari komunikasi antara komputer dengan mikrokontroller akan ditampilkan pada LCD 16X2 sehingga diharapkan akan mudah dalam proses pembangunan dan koreksi apabila ditemukan kesalahan pemrograman. Berikut ini adalah potongan program dari kontrol pergerakan motor DC.

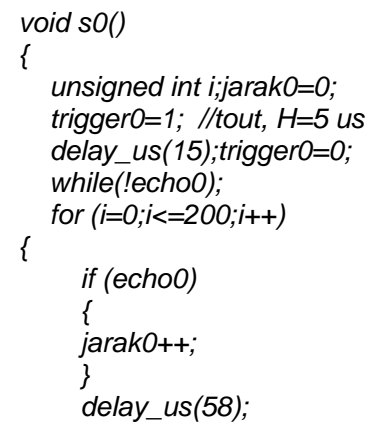




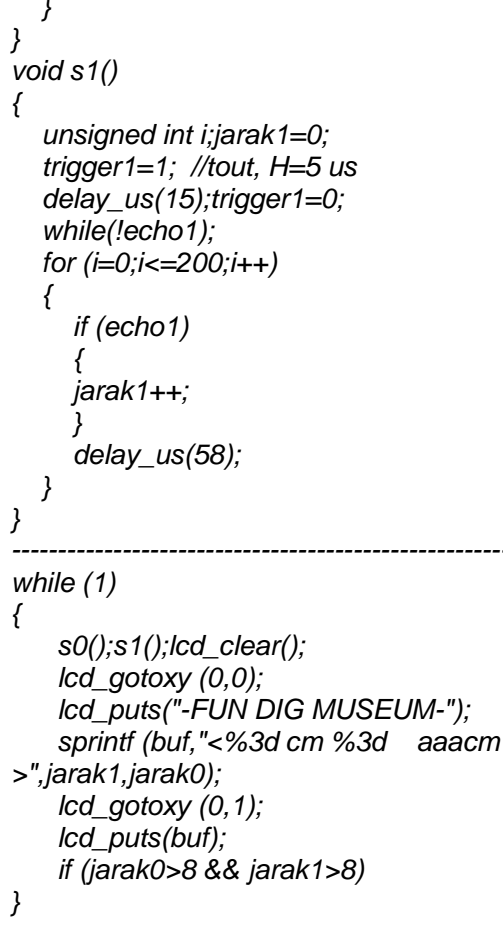

Selain mampu membaca jarak, sistem Mikrokontroller juga akan merespon input dari computer untuk melakukan gerak geser kiri dan kanan (sliding), sehingga sistem mampu bekerja sesuai panjang jalur yang telah ditentukan. Berikut ini adalah potongan program dari kontrol putaran motor DC.

void kanan()

OCR1A=255; PORTB. $6=0 ;$ PORTB. $7=1$;

void kiri()

OCR 1 A $=255 ;$ PORTB. $6=1 ;$ PORTB. $7=0 ;$

void stop()

OCR $1 \mathrm{~A}=0$; PORTB. $6=0 ;$ PORTB $.7=0$;

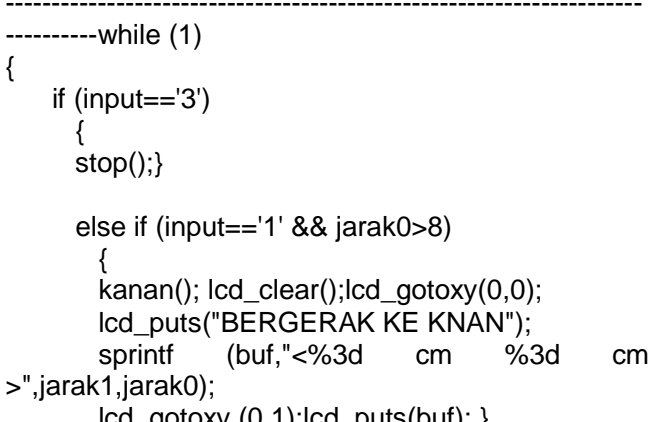

Icd_gotoxy (0,1);Icd_puts(buf); \}

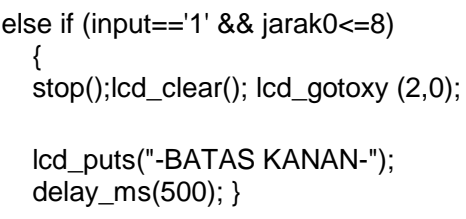

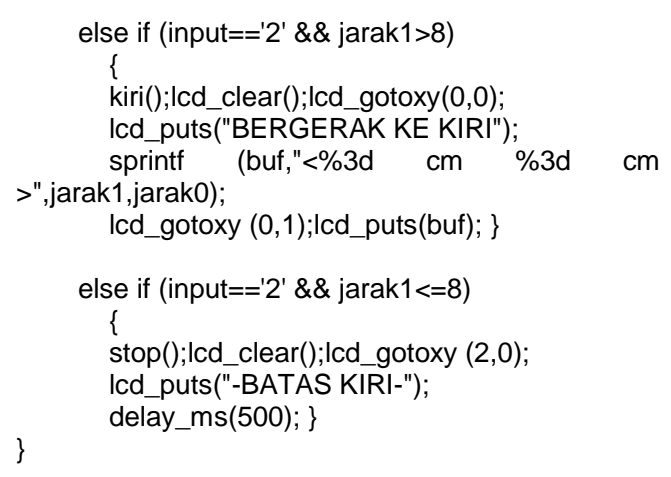

\section{Pengujian Fungsionalitas Sistem}

Pengujian fungsional didasarkan pada keberfungsian dari implementasi pergerakan smart sliding window, antarmuka pengguna dan navigasi melalui sensor Kinect. Berikut adalah tabel pemetaan hasil pengujian fungsionalitas smart sliding window.

\begin{tabular}{|c|c|c|}
\hline Spesifikasi & Implementasi & Keterangan \\
\hline Pergerakan motor & Mampu berjalan pada jalur & Berfungsi \\
\hline Komunikasi sistem & $\begin{array}{l}\text { Perintah dari komputer ke sistem } \\
\text { mikrokontroller dapat berjalan }\end{array}$ & Berfungsi \\
\hline Indikator jarak & $\begin{array}{l}\text { Smart sliding window mampu mendeteksi } \\
\text { jarak kiri dan jarak kanan jalur }\end{array}$ & Berfungsi \\
\hline Sensor pengguna & $\begin{array}{l}\text { Kinect mendeteksi pengguna sesuai dengan } \\
\text { kriteria yang telah ditentukan pada sistem }\end{array}$ & Berfungsi \\
\hline $\begin{array}{l}\text { Webcam ke arah } \\
\text { artefak }\end{array}$ & $\begin{array}{l}\text { Webcam yang di arahkan pada artefak } \\
\text { mampu di munculkan pada sistem smart } \\
\text { sliding window }\end{array}$ & Berfungsi \\
\hline Overlay marker & $\begin{array}{l}\text { Dalam tampilan webcam, muncul marker } \\
\text { yang dapat dimanfaatkan oleh pengunjung } \\
\text { untuk interaksi lebih lanjut }\end{array}$ & Berfungsi \\
\hline Tombol virtual & $\begin{array}{l}\text { Marker yang dijadikan tombol virtual dapat } \\
\text { digunakan oleh pengunjung melalui } \\
\text { pergerakan tangan }\end{array}$ & Berfungsi \\
\hline Memutar video & $\begin{array}{l}\text { Sistem mampu memutar video sesuai dengan } \\
\text { arah tangan yang menuju tombol marker }\end{array}$ & Berfungsi \\
\hline $\begin{array}{l}\text { Menutup atau } \\
\text { mematikan video }\end{array}$ & $\begin{array}{l}\text { Dengan lambaian tangan, video dapat } \\
\text { dimatikan }\end{array}$ & Berfungsi \\
\hline
\end{tabular}

Tabel 1 Hasil Pengujian Fungsionalitas Smart Sliding Window.

\section{Pengujian Pada Pengguna}

Pengujian pada pengguna dilakukan untuk mengetahui keberhasilan pada aspek user interface satisfaction dan usabilitas dari aplikasi sistem smart sliding window. Pengujian dilakukan dengan tekik kuisioner dan wawancara terhadap pengunjung Museum Geoilogi Bandung dengan jumlah 30 responden dengan rentang usia 11 - 40an tahun.

Kuisioner berisi 20 pertanyaanberdasarkan analisa aspek kepuasan antarmuka pengguna berdasarkan Chin, JP, Diehl, VA, Norman, KL (1988) Development of an Instrument Measuring User Satisfaction of the HumanComputer Interface ACM CHI'88 Proceedings, 213218.. () 1988 ACM.

dengan pilihan jawaban menggunakan skala Likert berupa lima (5) buah pilihan interval. Instrumen kuisioner diuji validitasnya dengan menggunakan teknik koefisien Pearson dan diuji reabilitasnya dengan teknik koefisien Alpha Cronbach, menggunakan bantuan program SPSS versi 17.0. 
Berdasarkan uji reabilitas, diperoleh nilai koefisien Alpha Cronbach 0,914 (mendekati nilai 1), yang menunjukkan bahwa pengukuran terhadap parameter penelitian ini realible dan dapat memberikan hasil yang konsisten.

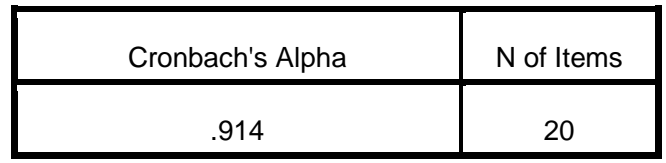

Tabel 2 Hasil Pengujian Reabilitas Cronbach Alfa.

Berikut ini hasil perhitungan secara lengkap tanggapan responden berdasarkan analisa aspek kepuasan antarmuka pengguna.

1. Reaksi umum tentang desain smart sliding window

\begin{tabular}{|c|l|c|c|c|c|c|}
\hline No. & \multicolumn{1}{|c|}{ Pertanyaan } & SS & S & KS & TS & TB \\
\hline 1 & (Bagus - Jelek) & 3 & 14 & 7 & 6 & 0 \\
\hline 2 & $\begin{array}{l}\text { (Mudah - Sulit) } \\
\text { (Bermanfaat - Tidak }\end{array}$ & 11 & 14 & 6 & 6 & 2 \\
\hline 3 & $\begin{array}{l}\text { (Bermanfaat) } \\
\text { (Menyenangkan - } \\
\text { Membosankan) }\end{array}$ & 11 & 13 & 2 & 4 & 0 \\
\hline \multicolumn{2}{|c|}{ Rata-rata } \\
\hline
\end{tabular}

2. Layar/tampilan monitor

\begin{tabular}{|c|c|c|c|c|c|c|}
\hline No. & Pertanyaan & SS & $S$ & KS & TS & TB \\
\hline 5 & $\begin{array}{l}\text { Kemudahan membaca } \\
\text { karakter di layar }\end{array}$ & 7 & 17 & 3 & 3 & 0 \\
\hline 6 & $\begin{array}{l}\text { Kesederhanaan } \\
\text { tampilan yang mudah } \\
\text { dipelajari }\end{array}$ & 6 & 17 & 3 & 3 & 1 \\
\hline
\end{tabular}

3. Belajar

\begin{tabular}{|c|l|c|c|c|c|c|c|}
\hline No. & \multicolumn{1}{|c|}{ Pertanyaan } & SS & S & KS & TS & TB & $\begin{array}{c}\text { Rata- } \\
\text { rata }\end{array}$ \\
\hline 7 & $\begin{array}{l}\text { Kemudahan pengoperasian } \\
\text { sistem }\end{array}$ & 9 & 14 & 2 & 5 & 0 & 4,11 \\
\hline 8 & $\begin{array}{l}\text { Kemudahan istilah dan } \\
\text { perintah yang digunakan }\end{array}$ & 6 & 16 & 3 & 4 & 1 & 3,98 \\
\hline 9 & $\begin{array}{l}\text { Kebermanfaat bantuan } \\
\text { pesan yang muncul di } \\
\text { layar }\end{array}$ & 13 & 13 & 0 & 4 & 0 & 4,23 \\
\hline \multicolumn{1}{c|}{ Rata-rata } \\
\hline
\end{tabular}

4. Kemampuan Sistem

\begin{tabular}{|c|c|c|c|c|c|c|c|}
\hline No. & Pertanyaan & SS & $S$ & KS & TS & TB & $\begin{array}{l}\text { Rata- } \\
\text { rata }\end{array}$ \\
\hline 10 & $\begin{array}{l}\text { Sistem cepat untuk } \\
\text { dapat digunakan }\end{array}$ & 5 & 18 & 4 & 3 & 0 & 4,06 \\
\hline 11 & Keandalan sistem & 13 & 15 & 0 & 2 & 0 & 4.19A \\
\hline 12 & $\begin{array}{l}\text { Sistem cenderung } \\
\text { tenang dan tidak } \\
\text { berisik }\end{array}$ & 11 & 14 & 2 & 3 & 0 & $4[2]]$ \\
\hline 13 & $\begin{array}{l}\text { Sistem mampu } \\
\text { memberikan bantuan } \\
\text { pengetahuan yang } \\
\text { lebih baik }\end{array}$ & 3 & 13 & 7 & 7 & 0 & \\
\hline \multicolumn{7}{|c|}{ Rata-rata } & \\
\hline
\end{tabular}

Berikut ini hasil perhitungan tanggapan responden berdasarkan analisa aspek usability pengguna berdasarkan Lewis, JR (1995) IBM Computer Usability Satisfaction Questionnaires: Psychometric Evaluation and Instructions for Use International Journal of Human-Computer Interaction, 7:1, 57-78.

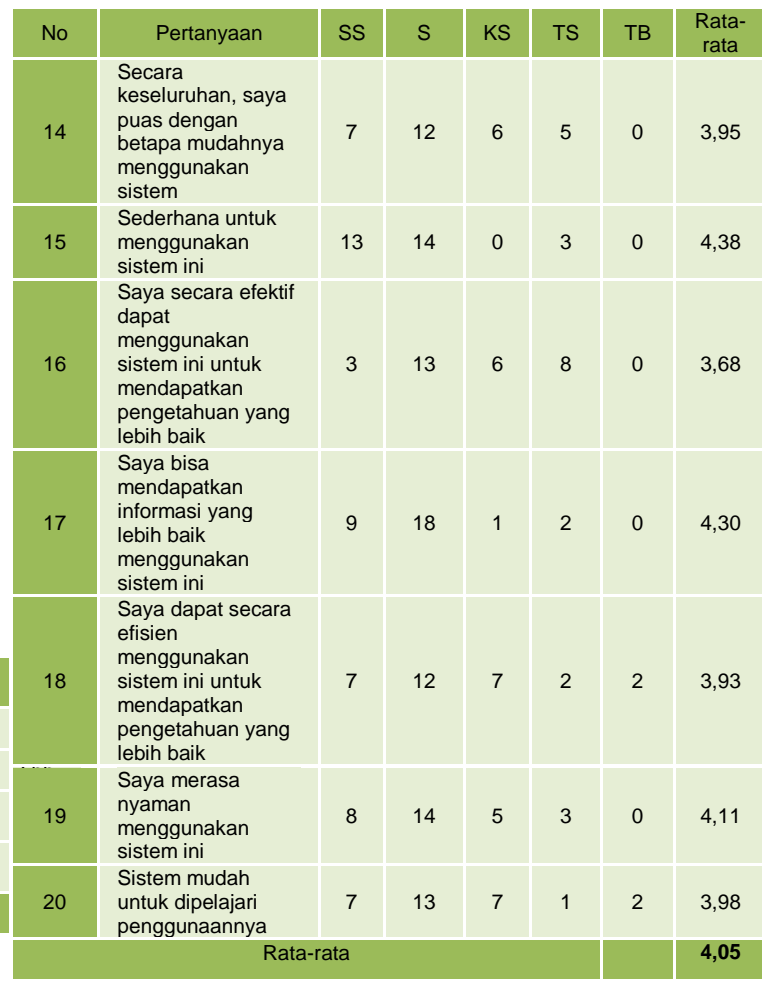

\section{KESIMPULAN}

Berdasarkan hasil pengujian yang telah dilakukan 4pada bab sebelumnya, beberapa kesimpulan dapat dijelaskan sebagai berikut.

Hasil pengujian aspek kepuasan antarmuka pengguna dan usabilitas menggunakan dasar evaluasi Chip, JP, Diehl, VA. Norman, KL (1988) dan Lewis, JR (1995), menunjukkan bahwa Smart Sliding Window dapat memberikan kepuasan antarmuka dengan fungsi yang cocok bagi pengguna dan memberikan kontrol serta kebebasan bagi pengguna, fleksibel, dan minimalis.

3 Smart Sliding Window memberikan manfaat pembelajaran yang lebih baik dalam mengenal benda geologi dan sejarah yang ada di Museum Geologi Bandung.

3 Hasil pengujian aspek usability menunjukkan bahwa pengguna dapat memperoleh manfaat dari keberadaan sistem, dan mudah untuk digunakan.

\section{DAFTAR PUSTAKA} https://uwaterloo.ca /mechanical-mechatronicsengineering/future-undergraduate-students/ mechatronics-engineering, 13 Mei 2013, $12.00 \mathrm{WIB}$. Wulandari, Suci., Analisis faktor-faktor yang mempengaruhi keinginan berkunjung ke museum dan implikasinya terhadap strategi pemasaran museum, http://lontar.ui.ac.id/opac/themes/libri2/detail.jsp?id=828 44\&lokasi=lokal, 13 Mei 2013, 14.00 WIB.

[3] Preece, J., Rogers, J., and Sharp, N., Interaction design : beyond human-computer interaction, USA, 2002. 


\section{SYSTEMIC}

Vol. 1, No. 2, Desember 2015, 1-7

[4] .., Prototyping Definition, 2012,

http://www.pcmag.com/ encyclopedia_term/0,1233,t=

prototyping\&i=49886,00.asp, 13 Mei 2013, 14.30 WIB.

[5] Kenneth E. Lantz, The prototyping methodology, Prentice-Hall, 1986.

[6] Andrianto, H., Pemrograman mikrokontroler AVR Atmega16, Informatika: Bandung, 2008. 